Asian J. Med. Biol. Res. 2015, 1 (2), 254-258; doi: 10.3329/ajmbr.v1i2.25619

\author{
Asian Journal of \\ Medical and Biological Research \\ ISSN 2411-4472 (Print) 2412-5571 (Online) \\ www.ebupress.com/journal/ajmbr
}

\title{
Article \\ Effect of modified feeding practice on milk production of cross bred dairy cows in Baghabari milk shed area, Sirajgonj
}

\author{
Md. Zillur Rahman ${ }^{1}$, Md.Yousuf Ali $^{1}{ }^{*}$, N.R. Sarker ${ }^{1}$, M. F. Afroz ${ }^{1}$, M.O.A. Rahman ${ }^{2}$ and M.R. Karim ${ }^{1}$ \\ ${ }^{1}$ Bangladesh Livestock Research Institute, Savar, Dhaka-1341, Bangladesh \\ ${ }^{2}$ Regional Station Bangladesh Livestock Research Institute, Baghabari, Shahjadpur, Sirajgonj,Bangladesh
}

${ }^{*}$ Corresponding author: Md.Yousuf Ali, Bangladesh Livestock Research Institute, Savar, Dhaka-1341, Bangladesh. Mobile: +8801717354092; E-mail: 113yousuf.bau@gmail.com

Received: 22 July 2015/Accepted: 24 August 2015/ Published: 30 September 2015

\begin{abstract}
A research work was undertaken to find out alternative feeding practices for dairy cows in Baghabari milk shed areas. The trial was conducted in the village Alokdiar, Shajadpur, Sirajgonj. Twenty cross bred lactating dairy cows of $340 \pm 15.5 \mathrm{~kg}$ live weight were used for the trial. Animals were equally and randomly allocated dietary into four groups, $\mathrm{T}_{0}$ (Rice straw + concentrate), $\mathrm{T}_{1}($ Napier silage + concentrate $), \mathrm{T}_{2}($ Khesari hay + concentrate) and $\mathrm{T}_{3}$ (UMS + concentrate). There was no significant difference in total DM intake among the four groups. The DCP $(\mathrm{kg} / \mathrm{d})$ intake was significantly $(\mathrm{P}<0.01)$ differ among the treatment group. The highest DCP $(\mathrm{kg} / \mathrm{d})$ intake was observed in $\mathrm{T}_{2}(0.824)$ followed by $\mathrm{T}_{1}(0.739), \mathrm{T}_{3}(0.707)$ and $\mathrm{T}_{0}(0.510)$. Higher CP content in Khesari hay which reflected DCP intake. The ME $(\mathrm{MJ} / \mathrm{d})$ intake was also significant $(\mathrm{P}<0.05)$ difference among the dietary groups. $\mathrm{ME}(\mathrm{MJ} / \mathrm{d})$ was the highest 93.46 in $\mathrm{T}_{2}$ afterward 92.21 in $\mathrm{T}_{3}$ and lowest 77.56 in $\mathrm{T}_{0}$. The average milk yield (1/d) was the highest in $\mathrm{T}_{2}(10.76)$ followed by $\mathrm{T}_{3}(10.13), \mathrm{T}_{1}(9.86)$ and $\mathrm{T}_{0}$ (7.31), respectively. Apparent digestibility were significant $(\mathrm{P}<0.05)$ variation among the dietary groups of animals in case of DM, OM and CP. The highest DM digestibility was observed in $\mathrm{T}_{2}$-Khasari based diet

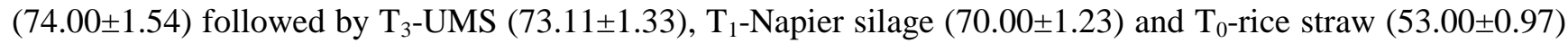
based diet, respectively. Introduction of legume hay as modified feeding practice may be an alternative feeding system to sustain milk production during lean period.
\end{abstract}

Keywords: khesari hay; silage; UMS; digestibility

\begin{abstract}
1. Introduction
Baghabari area is situated in Shahjadpur upazila which is commonly known as Milk pocket area (AEZ-4) and the country's only large scale dairy co-operative union is situated here. Baghabari area was selected as study area as the area is one of the most important milk pocket area of the country, where the cattle are mostly crossbred of local cows with Holstein-Friesian. Feeding of dairy cattle in the tropics and sub tropics is often difficult because of deficiencies in feed supply, in both quality and quantity (Wanapat and Devendra, 1992). There are two types of feeding system- bathan and non bathan (stall feeding) feeding system. In bathan feedig system, legume forages-matikalai (Vigna mungo) and khesari (Lathyrus sativus) were cultivated just after receding flood and the animals grazed on these forages up to middle of February. Thereafter, they were fed napier, jumbo, baksha or maize which were cultivated just after the flood receded. Feeding of these nonleguminous forages to cows was continued until late July when rainy season started. The rainy season commences from July and continues till October. With the above system in operation the farmers produce 1.62 million tonnes milk per day (Saha and Haque, 2001). This amount of milk production can cover only 15 per cent of the requirement. In the last few years milk consumption has increased rapidly and linearly with an estimated $1.2 \%$ increase annually (DLS, 2007). The area is crisscrossed with several rivers and thus the land is
\end{abstract}


inundated with floodwater about four months in a year, from July to October and the land covered with a high layer of silt after the floodwater recedes. During the rainy season of the year, cattle are stall-fed at home and this period generally shows the scarcity of cattle feeds specially roughages. Farmers usually give some concentrates to their dairy cows during this period to supplement rice straw both of which are expensive during this lean period. The animals in this season remain deficient protein intake. Finally milk production of dairies has drastically reduced this season. In winter season supply of green forage Lathyrus sativus was the highest since there were plenty of legume forages available in bathan area. Surplus legumes and napier grass can be preserved as hay and silage, respectively for feeding when deficiency of nutrients prevails during rainy season. To consider the above existing farmers situation, BLRI regional station set a trial within the surrounding village (Alokdiar) with the objectives to find out alternative feeding practices for dairy cows.

\section{Materials and Methods}

\subsection{Site of the experiment}

The trial was conducted in the village Alokdiar, Shajadpur, Sirajgonj.

\subsection{Duration of the experiment}

Seventy five days.

\subsection{Legume (Khesari) hay and silage preparation}

Khesari was cultivated for legume hay preparation. There were five plots and each plot had 33 decimal. Napier was cultivated for silage preparation. Napier cutting was supplied to the selected farmers. The plot size for fodder production of each animal was 33 decimal. The farmers planted the Napier cutting on 10 November/2013 and silage was prepared in the field condition.

\subsection{Selection, grouping and housing of animals}

The animals were randomly distributed in four groups each having five animals. The groups were designed as $\mathrm{T} 0$, T1, T2, and T3. The animal grouping was done in such a way that the mean live (kg) weight and milk production (1/d) of all the groups was almost similar. The animals housed individually in animal shed subjected to adequate natural ventilation and sunlight. The animals were dewormed with LT-Zol-Vet, ear tagged and then allowed for 14 days to adjust with experimental diets and management prior to commencement of the trial.

\subsection{Dietary treatments}

Four diets were prepared and considered as four dietary treatments, $T_{0}$ (Rice straw+concentrate), $\mathrm{T}_{1}$ (Napier silage+concentrate), $\mathrm{T}_{2}$ (Khesari hay+concentrate) and $\mathrm{T}_{3}$ (UMS+concentrate). The concentrate part of the ration consisted of wheat bran (14\%), Khesari bran (13\%), lentil bran (19\%), rice polish 15\%), pea bran (11\%), matikali bran (18\%) til oil cake (9\%) and salt (1\%). The concentrate mixture contains $18 \% \mathrm{CP}$ and $10.31 \mathrm{MJ}$ $\mathrm{ME} / \mathrm{kg} \mathrm{DM}$. The daily required amount of feed was portioned into two for feeding to the animals in the morning at 7:00 hours and afternoon at 16:00 hours. Concentrate was supplied first followed by roughages. No refusal of concentrate mixture was found in any case. Fresh and clean drinking water was available for all the animals. Feces and urine were collected individually during the last 7 days of the digestion trial.

\subsection{Measurement of feed intake and sample collection}

The roughage intake of each animal was determined by subtracting the amount of left over if any from the amount of feed given on the previous day. Refusal was collected every morning before feed supply and weighed to determine daily feed intake. During the experimental period, the animals consumed all of the concentrate. For metabolism trial output of faeces and urine was recorded daily during the last 7 days of the feeding trial period. The quantity of feed, refusal and feces were weighed daily and representative samples were kept for analysis. Faeceswas collected at every 8:00 am and 24 hours interval, weighed and sub-sample was taken every day in plastic bags. Samples of faeces were stored in the freezer $\left(-20^{\circ} \mathrm{C}\right)$. Urine sample was collected in a bucket containing $6 \mathrm{~N} \mathrm{H}_{2} \mathrm{SO}_{4}$ solution to maintain a $\mathrm{pH}$ of 4 or lower and taken $10 \%$ sub-sample and stored in freezer at $-20{ }^{\circ} \mathrm{C}$ until analysis.] 


\subsection{Chemical analysis of samples}

All the samples of feeds and faeces were prepared and sub-samples were used for analysis. The samples were subjected to chemical analysis for the determination of dry matter (DM), organic matter (OM) and ash following the methods of AOAC (1995). All the samples were analyzed and the mean values were recorded.

\subsection{Statistical analysis}

The statistical analysis was done using 'SPSS-11.5' statistical program to compute analysis of variance (ANOVA) in completely randomized design (Steel and Torrie, 1980). Differences among the treatment means were determined by Duncan's Multiple range Test (DMRT) (Duncan, 1955).

\section{Results and Discussion}

\subsection{Chemical composition of feedstuffs}

The chemical composition of feeds used in the trial is given in Table 1. It can be seen from the table that the CP contents of Khesari hay, Napier silage, UMS and straw were 15.24, 11.43, 8.11 and 3.11\%, respectively.

Table 1. Chemical composition of feed stuffs.

\begin{tabular}{|l|l|l|l|l|l|}
\hline \multirow{2}{*}{ Feed ingredients } & \multirow{2}{*}{$\begin{array}{l}\text { \%DM } \\
\text { fresh basis }\end{array}$} & \% DM basis & OMh & CP & ADF \\
\cline { 2 - 6 } & 17.65 & 88.77 & 11.23 & 11.43 & 46.88 \\
\hline Napier silage & 89.35 & 93.68 & 6.32 & 15.24 & 61.11 \\
\hline Khesari hay & 66.34 & 87.79 & 12.21 & 8.11 & 47.23 \\
\hline UMS & 89.23 & 86.74 & 13.26 & 3.11 & 65.21 \\
\hline Straw & 91.43 & 91.15 & 8.85 & 18.00 & 28.48 \\
\hline Concentrate mixture & & & & \\
\hline
\end{tabular}

Table 2. Feed intake and milk yield of cross bred dairy cows fed different diets.

\begin{tabular}{|c|c|c|c|c|c|}
\hline \multirow{2}{*}{ Intake and production } & \multicolumn{4}{|c|}{ Dietary treatments } & \multirow{2}{*}{$\begin{array}{l}\text { Level of } \\
\text { sig. }\end{array}$} \\
\hline & $\mathbf{T}_{\mathbf{0}}$ & $T_{1}$ & $\mathbf{T}_{2}$ & $\mathbf{T}_{3}$ & \\
\hline Rice straw DM (kg/d) & 7.10 & - & - & - & \\
\hline $\begin{array}{l}\text { Concentrate mixture DM } \\
(\mathrm{kg} / \mathrm{d})\end{array}$ & 5.20 & 5.00 & 4.70 & 4.82 & \\
\hline Silage DM $(\mathrm{kg} / \mathrm{d})$ & - & 7.56 & - & - & \\
\hline Hay DM $(\mathrm{kg} / \mathrm{d})$ & - & - & 7.76 & - & \\
\hline UMS DM $(\mathrm{kg} / \mathrm{d})$ & - & - & - & 7.54 & \\
\hline Total DM (kg/d) & $12.30 \pm 0.91$ & $12.56 \pm 0.56$ & $12.46 \pm 0.43$ & $12.36 \pm 0.65$ & NS \\
\hline DMI/100kgLW & $3.43 \pm 0.51$ & $3.50 \pm 0.43$ & $3.47 \pm 0.72$ & $3.44 \pm 0.56$ & NS \\
\hline $\mathrm{DCP}(\mathrm{kg} / \mathrm{d})$ & $0.510^{\mathrm{C}} \pm 0.38$ & $0.739^{\mathrm{b}} \pm 0.94$ & $0.824^{\mathrm{a}} \pm 0.76$ & $0.707^{\mathrm{b}} \pm 0.62$ & ** \\
\hline $\mathrm{ME}(\mathrm{MJ} / \mathrm{d})$ & $77.56^{\mathrm{b}} \pm 0.89$ & $88.92^{\mathrm{a}} \pm 0.69$ & $93.46^{\mathrm{a}} \pm 0.67$ & $92.21^{\mathrm{a}} \pm 0.87$ & $*$ \\
\hline Milk yield (l/d) & $7.31^{\mathrm{b}} \pm 0.65$ & $9.86^{\mathrm{a}} \pm 0.88$ & $10.76^{\mathrm{a}} \pm 0.88$ & $10.13^{\mathrm{a}} \pm 0.87$ & $* *$ \\
\hline
\end{tabular}

${ }_{\text {abc }}$ Mean values in a row with different superscripts differ significantly; NS= Not significant, $* \mathrm{P}<0.05 ; * \mathrm{P}<0.01$.

Table 3. Digestibility (\%) of different nutrient.

\begin{tabular}{|l|l|l|l|l|l|}
\hline Parameter & $\mathbf{T}_{\mathbf{0}}$ & $\mathbf{T}_{\mathbf{1}}$ & $\mathbf{T}_{\mathbf{2}}$ & $\mathbf{T}_{\mathbf{3}}$ & $\begin{array}{l}\text { Level ol } \\
\text { significance }\end{array}$ \\
\hline DM & $53.00^{\mathrm{b}} \pm 0.97$ & $70.00^{\mathrm{a}} \pm 1.23$ & $74.00^{\mathrm{a}} \pm 1.54$ & $73.11^{\mathrm{a}} \pm 1.33$ & $*$ \\
\hline CP & $58.00^{\mathrm{b}} \pm 0.98$ & $77.00^{\mathrm{a}} \pm 0.89$ & $79.00^{\mathrm{a}} \pm 1.11$ & $74.12^{\mathrm{a}} \pm 0.14$ & $*$ \\
\hline OM & $53.50^{\mathrm{c}} \pm 0.99$ & $78.60^{\mathrm{a}} \pm 0.67$ & $69.70^{\mathrm{b}} \pm 1.32$ & $76.79^{\mathrm{a}} \pm 1.22$ & $*$ \\
\hline
\end{tabular}

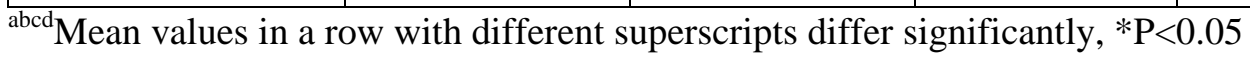

\subsection{Feed intake and milk production}

The average values for nutrient intakes (DM, DCP and ME) in different treatment group are shown in Table 2. The study revealed that there was no significant difference in total DM intake among the four groups. The DCP $(\mathrm{kg} / \mathrm{d})$ intake was significantly $(\mathrm{P}<0.01)$ differed among the treatment group. The highest DCP $(\mathrm{kg} / \mathrm{d})$ intake was observed in $\mathrm{T}_{2}(0.824)$ followed by $\mathrm{T}_{1}(0.739), \mathrm{T}_{3}(0.707)$ and $\mathrm{T}_{0}(0.510)$. Higher CP content in Khesari hay which reflected DCP intake. The ME $(\mathrm{MJ} / \mathrm{d})$ intake was also significant $(\mathrm{P}<0.05)$ difference among the dietary 
groups. The ME (MJ/d) was the highest 93.46 in $\mathrm{T}_{2}$ afterward 92.21 in $\mathrm{T}_{3}$ and lowest 77.56 in $\mathrm{T} 0$. The average milk yield (1/d) was the highest in $\mathrm{T}_{2}$ (10.76) followed by $\mathrm{T}_{3}(10.13), \mathrm{T}_{1}(9.86)$ and $\mathrm{T}_{0}(7.31)$, respectively. Kawas et al. (1989) stated that diets with pre-bloom alfa alfa hay produced more milk than non-hay diets. This mixing may be done in pot, or in a container such as basket lined with mud or even on the floor. It is advantageous to add a meal containing urease (e.g. soybean meal, legume beans, middling soil or even livestock excreta (khan et al., 1990). The results showed that milk yield was related to feed intake. It is interesting to note that although concentrates were supplied in higher quantities in all groups, yet milk yield was lower in $\mathrm{T}_{0}$. This may due to the difference in basal diet. The higher the ambient temperature, the shorter the time needed for digestibility to be increased (Jayasuriya, 1984). Evidence for the reaction taking place is a change in color of the fibrous material usually to a bright yellow. Treated straw can be fed immediately following ammoniation. It must not be sun-dried as this result in a loss of gaseous ammonia. So it is suggested to maximize the milk production the modified feding system may be used in the time of crisis.

\subsection{Nutrient digestibility}

Digestibility of different nutrients is shown in Table 3. In Bangladesh most forages consumed by livestock are relatively low in digestibility (40-50\%). The metabolizable energy in the dry matter, thus ranges from 4.8-7.5 $\mathrm{MJ} / \mathrm{kg} \mathrm{DM}$ (Khan, 2000). Apparent digestibility values showed that these were significant $(\mathrm{P}<0.05)$ variation among the dietary groups of animals in case of DM, OM and CP. The highest DM digestibility was observed in Khasari based diet $(74.00 \pm 1.54)$ due to nitrogen contents followed by UMS $(73.11 \pm 1.33)$, Napier silage $(70.00 \pm 1.23)$ and rice straw $(53.00 \pm 0.97)$ based diet, respectively. According to feeding standards, a metabolizable energy content in a feed of 7.5 will support a gain of approximately $2 \mathrm{~g}$ MJ of ME intake in cattle. As a consequence of $4.8 \mathrm{MJ} / \mathrm{kg} \mathrm{DM}$, animal are usually in negative energy balance (ARC, 1980 and Webster, 1989). On the other hand, supplying urea with low quality forages growth rate of animal can be attained up to $18 \mathrm{~g} / \mathrm{MJ}$ of ME intake (Saadullah, 1984). Lactating animals

sometimes receive a concentrate feeds containing only in the milk shed areas (Bathan) recently adopt the use of balanced concentrate mixtures for feeding milking cows. However, they follow traditional feeding systems and do not know the scientific nutrient requirements developed by NRC, ARC, ICAR or others. That is to say, farmers do not use book valued and terms like ME, TDN, or DCP but they practice the standards on they have learned by their own experience. (Rangnekar, 1993; Jackson, 1980 and Shciere and de Wit, 1993). Farmers are bound to accept low production of their animals for economic reasons due to unavailability of good forage and high price of concentrates (khan et al 2009).

\section{Conclusions}

In conclusion, introduction of Khesari (legume) hay as modified feeding practice may be an alternative feeding system to sustain milk production during lean period.

\section{Conflict of interest}

None to declare.

\section{References}

AOAC, 1995. Official Methods of Analysis. (16 ${ }^{\text {th }}$ edition), Association of Official Analytical Chemist. Washington D.C.

Agricultural Research Council (ARC), 1980. The Nutrient Requirement of Ruminant Livestock. Commonwealth Agricultural Bureau, London, SWIY 5 AG.

DLS (Directorate of Livestock Services), 2007. Department of Livestock Services An overview, DLS, Dhaka, Bangladesh.

Duncan DB, 1955. Multiple Range and Multiple F-tests. Biometrics, 11: 1-42.

Jackson MG, 1980. Who needs feeding standard? Anim. Feed Sci. and Tech., 6: 101-104.

Kawas JR, NA Jorgensen, AR Hardie, M Collins and GP Barrington, 1989. Assessment of alfalfa quality with change in maturity and concentrate level. Univ. of Wisconsin-Madison College of Ag. and Life Sciences, Rep. No. R3460.

Khan MJ, KJ Peters and MM Uddin. 2009. Feeding Strategy for improving dairy cattle productivity in small holder farm in Bangladesh. Bang. J. Anim. Sci., 38: 67 - 85. 
Rangnekar DV, 1893. Farmer perceptions of quality and value of feeds, fodder and feeding. Proceeding Investigations on agricultural waste materials for evolving economic rations for livestock workshop, Poona, India.

Saadullah M, 1984. Studies on Utilization of rice straw by cattle. PhD thesis, Royal Veterinary College, Copenhagen

Saha GC and SAMA Haque, 2001. Small-scale processing and marketing in Bangladesh including reference to micro-credit facilities (good market access)-Milk Vita: A case study. ILRI proceedings, Edit. D. Rangnekar and W. Thorpe, Nairobi, Keneya, pp. 327.

Schiere JB and J De Wit, 1993. Feeding standards and tropical feeding systems. Anim. Feed Sci. and Tech., 5: 93-98.

Steel RGD and JH Torrie, 1980. Principles and Procedures of Statistics: A Biometric Approach, $2^{\text {nd }}$ edition.mcGraw-Hill kapagakusha Ltd., Tokyo, Japan.

Wanapat M and C Devendra, 1992. Feeding and nutrition of dairy cattle and buffaloes in Asia. Sustainable Animal Production. In: Proceedings 6th AAAP Animal Science Congress, Bangkok, Thailand. pp. 177-194.

Webster AVF, 1989. Bioenergetics, bioengineering and growth. Animal Production, 48: 249-69. 